\title{
Christian scholarship and Calvinistic or Christian philosophy
}

\author{
In the circles of Christian scholarship the idea \\ of a Christian or Calvinistic philosophy is a fam= \\ iliar notion. Outside of these circles there seem \\ to exist very little familiarity with the underly= \\ ing motivations which have given rise to such an \\ academic endeavour or with the type of problems \\ which are focussed upon in this approach. This \\ article is primarily intended for consumption out= \\ side of the reformed and of this notion. More= \\ over the article is of a popular scientific nature \\ and has no intention of giving an exhaustive expo= \\ sition of these problems or the discussion concern= \\ ing them. \\ To understand the contribution of the Reformed \\ world and life view and way of life to the develop= \\ ment of the ideal of a Christian philosophy and \\ Christian science the historical roots of the Cal= \\ vinistic world and life view have to be traced and \\ the links between these historical roots and the \\ developments in South Africa have to be established. \\ Afrikaner Calvinism; especially the specific brand \\ of "Gereformeerde"l) Calvinism can not be separated \\ from its historical links with Dutch Calvinism. \\ It this holds for Calvinism as a general way of \\ life this is definitely true with respect to Cal= \\ vinistic thought, and more specifically with res= \\ pect to philosophical and scientific thought, for \\ Afrikaner Calvinism has to a large extent been \\ orientated primarily towards Dutch Calvinism. \\ This link has been especially significant in theo= \\ logy and philosophy but is also important in the
}


humanities in general.

The fundamental idea which has been typical of Dutch Calvinism and which characterized the speci= fic Calvinistic world and life view was transplant= ed in South Africa via the South African Dutch Re= formed churches of which the "Gereformeerde Kerk" is one.

It must be stated that Calvinism in South Africa has developed different nuances. In this respect the typical "brand" of Calvinism of the Reformed Church and the accompanying Calvinistic world and life view which has permeated many facets of South African society outside of official the domain of the Reformed Church as such, can be distinguished from the overall Protestant-Calvinistic approach to science must be seen as the result of a speci= fic orientation toward life, one in which religion and life are not separated into different compart= ments but united and integrated. Also in the field of science and philosophy Calvinists have stressed and affirmed the importance and relevance of faith.

Science as one of the many aspects of life in which a Christian has a task, is accepted as a divine vocation and as such it also stimulated the idea of the scientific research of reality as a calling.

The historical link between Dutch and South African Calvinism has been expounded more comprehensively elsewhere but it is necessary to give an outline of some of the more important historical channels of thought which functioned as connecting historic= al links in the process of the transplant of Dutch Calvinistic ideas to South African intellectual soil.

The most prominent and important figure in this respect is Abraham Kuyper who could be seen as one of the most important Dutch contributors to this conception and also one of the major forces in the development of what is later termed the Philosophy of Low or The Philosophy of the Cosmonomic Idea, which had a profound influence on the later development 
of Christian scholarship in South Africa.

The delineation and demarkation of the role of the Reformed Calvinistic philosophical tradition is especially important because this philosophy has had a profound influence on the spheres outside of the field of philosophy proper, especially in that of education. This has become marked - recogniz= able in the South African concept of "Christian National Education". This policy is historically connected with the Calvinistic idea that religious and scientific knowledge are intimately related.

The significance of a historical revue and evalua= tion of the idea of Christian scholarship becomes clear when the influence of the Calvinistic doc= trine of the epistemological significance of re= ligion on the practical policy of the controver= sial concept of Christian National Education is taken into account. Although it is difficult to trace the exact lines of development from Dutch Calvin= ism to the birth of similar ideals in South Afri= ca, it could be stated that the example of the Gereformeerde Kerk (Reformed Church) in Holland and the work of Abraham Kuyper directly influenced the development of Christian scholarship ideals and Calvinistic philosophy in South Africa via the South African Reformed church.

Apart from this channel the philosophy of Herman Dooyeweerd also constitutes a direct link in the development in the first half of this century. The Christian philosophy, from the beginning of its development to its first systematic expression in the work of Dooyeweerd, can only be understood as the fruit of the Calvinist awakening in Holland since the last decades of the nineteenth century, the movement which was led by Abraham Kuyper.

To give an impression of the basic problems with which a Calvinistic philosophy is concerned the main theses of such a philosophy will be discussed. The philosophy of Dooyeweerd is chosen as point of departure and the most important developments and deviations which can be traced in the philosophy of the idea of creation of $H$ G Stoker will then be pointed out. 
Basic problems

The year 1926 marks a milestone in the development of a so called "calvinistic" philosophy.

In Herman Dooyeweerd's inaugural address as profes= sor of Jurisprudence at the Free University of Am= sterdam on "De beteekenis der Wetsidee voor Rechts= wetenschap en Rechtsphilosophie" (The meaning of the idea of law for Jurisprudence and the philos= ophy of Jurisprudence), he sought a distinctively Christian foundation for his own special field of Jurisprudence along the lines already developed by Kuyper. Especially Kuyper's discovery of the Scriptural principle of the sovereignty of God as the basic idea of philosophy and Kuyper's ground= ing of all thought in the heart of man as the re= ligious focal point of human life were basic con= ceptions which radically influenced Dooyeweerd's at tempt to formulate such a distinctively christ= ian foundation.

The confession of the universality of the Kingship of Christ and the central confession of God's sovereignty as Creator over the whole coimos are the sources from which both Kuyper's ideas and Dooyeweerd's fundamental philosophical developments can be understood.

Dooyeweerd's philosophy incorporates Kuyper's idea of the religious antithesis in life and thought, interpreted not as a line of personal classifica= tion, but as a line of division according to fun= damental principles in the world - a line of divi= sion which passes transversely through the exis= tence of every Christian personality.2)

To formulate exactly what the contents of a Calvin= ist philosophy is, is not a simple matter - even the term "Calvinist" philosophy is rather mislead= ing in this context. 3 )

Various possible connotations could be given to this term. One possibility explored by A I Conra= die, is the possibility that it is a philosophy based on the fundamental ideas of calvin in the same manner as one would speak of a Thomist 
philosophy based on the basic conceptions of Thomas Aquinas. The fundamental problem, she points out, is the fact that Calvin never consciously, construc=
ted a systematic Calvinistic philosophy.

This becomes even more complicated when the evalua= tion of what Calvinistic philosophy is, is judged against the background of a statement made by Stoker in which he claims that the new philosophy of the Free University of Ansterdam has the preten= sion to remove a centuries old lack of Calyinism, namely the lack of a Calvinist philosophy.5)

In this sense, Conradie ${ }^{6)}$ points out, it is diffi= cult to interpret the term Calvinistic philosophy in the sense of a philosophy based on the philoso= phy of Calvin. Conradie' points out that Calvin= istic philosophy means philosophy which takes its principles from scripture. On this one fundament= al idea the diverse nuances of a Calvinistic phi= losophy more or less agree.

Problematic is also the term neo-Calvinism which is attributed to the whole movement which developed as the result of the work and ideals of Kuyper. This term is rejected by the followers of Kuyper and the tradition of the Gereformeerde kerke because the fundamental goal of the reformation of theolo= gy, science, the church and society was not so much a new form of Calvinism, but a return to the original principles formulated by Calvin.

Apart from the controversy about the term neoCalvinism, the question of the Calvinistic princi= ples reformulated by Kuyper could also be disputed.

The idea of a reformed philosophy practically imp= lied a radical reformation of philosophy in general and this is exactly what the whole movement of Cal= vinistic philosophy had in mind.

This philosophy tries to give expression to the profound religious motives of the protestant Refor= mation.

Dooyeweerd's immediate philosophical point of de= parture was a radical break with the philosophical 
view of reality which is rooted in the immanence standpoint. From here he is concerned to follow the basic reformatory insights of Kuyper and their implications for philosophy and to develop a phi= losophy from a transcendence point of view.

This involved Dooyeweerd in more general philoso= phical questions such as amongst others the inter= relationship of the various aspects of reality which constitute the field of enquiry of the differ= ent sciences. The principle of sphere sovereignty, at that stage already formulated by Kuyper, had not been applied specifically to this type of question. Dooyeweerd eleborated this principle in his idea of the sphere sovereignty of the different modal law spheres.

In this effort Dooyeweerd was from the outset assisted by his colleague Vollenhoven. Construc= tive criticism was also excercised by professor H G Stoker who contributed to the introduction and further development of this philosophy in South Africa.

Dooyeweerd's initial ideal of the formation of a circle of adherents who would examine philosophical problems but also work out the principles of the special sciences in the light of this philosophy of the cosmonomic idea, has meanwhile been realized.

It is important to note that Dooyeweerd does not wish to characterize Calvinistic or Christian phi= losophy as philosophy with religious presupposi= tions in contrast with philosophies with non-reli= gious presuppositions or no presuppositions at all. He wishes to show with a philosophical necessity that all philosophies are rooted in presuppositions of a religious nature. ${ }^{8}$ Dooyeweerd claims that his philosophy is regulated by the Christian basic motive of creation, the fall into sin and the re= demptive work of Christ. This implies that in his philosophy there is no room for a synthesis of Christian and non-Christian thought. Dooyeweerd's philosophy devotes special attention to the problem of presuppositions. The examination of the presup= positions of philosophical thought is crucial for the enterprise of theoretical enquiry into reality. 
For Dooyeweerd it is uncritical to assume that scientific and philosophical activity can exist apart from necessary non-theoretical apriori prin= ciples.

Dooyeweerd states that the very postulate of the neutral and autonomous character of theoretical thought is as such a presupposition of non-theor= etical nature. The philospher or scientist who does not acknowledge this is dogmatic and one of Dooyeweerd's prime concerns is to combat such dogmatism. Philosophy is by its very nature a re= ligiously determined act, it cannot be neutral, for the very proclamation of its neutrality is a religious choice.

Against this background Dooyeweerd approaches the problem of theoretical thought via a series of basic problems through which he intends to uncover the structural apriori which constitute the neces= sary conditions for all theoretical thought.10)

Historical investigation discloses for Dooyeweerd that basic religious motives directed the develop= ment of philosophy in different ways in different times, but the course of philosophic thought was always directed by a triad of transcendental ideas corresponding to the three basic problems of theo= retical thought.

The transcendental ideas are concerned with the coherence, totality and origin of all meaning. The question of the mutual relation and coherence of modal aspects, the question of their religious root, which expresses their totality of meaning and the question of origin constitute three as= pects of a single problem, answerable in terms of a transcendental basic idea, the basic idea of all philosophy. The content of the latter is direct= ly determined by a religious motive.11)

Each system of philosophy is directed by such an apriori conception of the origin and totality of meaning of the cosmic order. Dooyeweerd finds the content of his cosmonomic idea (literally meaning the idea of the laws governing the cosmos) in the central motive of the Christian religion, namely 
creation, the fall in sin and the redemption accom= plished by Christ. The Archimedean point of philosophy is found in Christ, the new religious root of the cosmos.

Dooyeweerd chooses the Archimedean point of his philosophy in the deeper root of all our human existence, the heart of man which participates in the totality of meaning, Jesus Christ.

In this respect Dooyeweerd once more departs from a Kuyperian notion and also follows Kuyper's exeg= esis of Eccles. 3:11. This specific exegesis has been criticised very sharply by different philos= ophers and is also seen as one of the points where the philosphy of the cosmonomic idea has most probably incorporated scholastic philosophical elements from the philosophy and theology of Kuyper.12)

The heart of man, in Scriptural terms seen as the point where the relation of God to man is deter= mined, is seen as the deepest centre of life. The heart of man cannot be neutral with respect to God. It is either renewed in Jesus Christ and thus be= longs to the regenerate humanity or else it lives in apostacy from God.

The abovementioned basic problems could be seen as the most important points of departure of the phi= losophy of the cosmonomic idea as initially formul= ated by Herman Dooyeweerd of the Free University of Amsterdam in the Netherlands. In South Africa the fundamental principles of Dooyeweerd's Calvinistic philosophy were introduced by prof H G Stoker. Although Stoker developed his own Calvinistic phi= losophy independantly of Dooyeweerd and Vollenho= ven he expressed his profound appreciation of this philosophy and also offered constructive criticism.

The fundamental difference between Dooyeweerd and Stoker centres around Dooyeweerd's presentation of the cosmonomic idea as the basic idea of philos= ophy.

Stoker claims that the idea of creation is the basic idea of a Calvinist philosophy. According 
to stoker this idea of creation encompasses the idea of law. He postulates that the cosmos is primarily a creation of God. God is not only Law= giver but the sovereign Creator of the cosmos.

For stoker there is no single principle to which the whole cosmos can be reduced. He distinguishes four so called cosmic dimensions by which he means to grasp all the universal perspectives of diver= sity in reality viz the dimensions of modalities, individual and social structures, events or occur= rences and values. The four perspectives in terms of which cosmic diversity can be explained accord= ing to stoker, presuppose one another in such a manner that it is impossible to abstract any one perspective as a final principle of unity. Stoker sees the cosmonomic idea with its account of the modal spheres and their relations as only one perspective in terms of which cosmic diversity can be explained.13)

A detailed description and exposition of the fun= damental differences between the philosophy of stoker and Dooyeweerd can be found elsewhere.14) It is not the purpose of this article to give a detailed exposition of these differences.

A few of the most salient points will be mentioned to give an overall impression of the scope of pro= blems which figure within the frame of refence of these two divergent philosophical systems originat= ing from the same fundamental motive of a radically Biblical Christian philosophy. Dooyeweerd's anthropological conception of the heart of man par= ticipating in the totality of meaning, Jesus Christ, and figuring as the religious centre of the whole of cosmic reality, is not accepted by stoker who claims that such a view is anthropocentric.

Stoker states that man has been created as the crown of God's creation but cannot function as the religious centre of creation because the totality of creation, apart from humanity, is directly re= lated to God and does not only stand in a relation= ship to God via mankind and its central religious concentration in Jesus Christ. This conception of stoker has in turn given rise to criticism from 
Dooyeweerd and others that this idea would mean a concession to the traditional substance idea which to a certain extent implies an independance of reality from God. Another fundamental point on which the conceptions of Dooyeweerd and Stoker digress is the qualification of reality as "mean= ing".

Dooyeweerd states that reality is meaning. This means that meaning is the creational mode of being of all reality which implies that all reality is totally dependent upon an origin which is not meaning but Who is the creator of meaning, $i \mathrm{e}$ God.15)

This view that created reality is meaning expres= ses the creatio ex nihile conception of scripture and implies a rejection of all other notions of the existence of original matter.

Stoker deviates from this formulation by stating that reality is not meaning but has meaning, by which he reintroduces a type of qualified "sub= stance-idea" which makes room for the already stated direct relationship of reality to God apart from the intermediate relationship which Dooye= weerd postulates in his philosphy.

These are only a few of the fundamental differences between the philosophy of law of Herman Dooyeweerd and the philosophy of the idea of creation of H G Stoker.

Amongst the philosophers who contributed to a typ= ical Calvinistic philosophical perspective in South Africa Stoker may be seen as one of the most important representatives of the reformed tradi= tion. Moreover he could be designated as the philosopher whose philosophy was a major contribu= tion to the ideal of Christian scholorly pursuit as it historically took shape in the idea of a Christian university.

He was of course not the only South African repre= sentative of a Calvinist philosophy, but he could be seen as the most important contributor to the typical reformed philosophy which has characterized 
the Calvinistic approach to science and which has also influenced many scientists of Calvinistic conviction in South Africa. When the contribution of Stoker is evaluated one soon recognizes the fact that his was an independant and to a large extent also original contribution to the idea of Calvinist philosophy..

Heyns states (6) that Stoker's philosophy is also permeated with the fundamental principle that faith is not only restricted to church and religion in the narrow sense of the word, but that it has to be made fruitful to all facets of life and cul= ture. This is the same basic idea which inspired Kuyper and Dooyeweerd in their efforts to formul= ate a Christian development of science and philos= ophy.

Contra atheism which does not accept the existence of God, and pantheism which accepts the whole of reality as God, stoker states his theism in which it is accepted that the triune God has revealed Himself to man as the Creator, Law-giver and Sus= tainer of heaven and earth. Because all of real= ity has been created by God and is sustained by God, every creature must serve God. This applies to science also. Where God is served in science there a Christian scholarship is established.

A great deal of Stoker's philosophical work was dedicated to this ideal of a Christian science and to the exposition of the fundamental principles and methods of science in general.

In his book Beginsels en metodes in die wetenskap (Prin= ciples and methods of science) he approaches the whole problem of Christian scholarship from three points of view.

From the point of view of the knowable he argues as follows: The scientist may not only accept the cosmos or the experience of reality as a source of knowledge. Scripture must also be used as such a source of knowledge. If the light of Scripture is not taken into account the work of such a scientist is unscientific. Scripture reveals truths which are important to science and which cannot be found 
by empirical research only.

According to Stoker Scripture not only contains truths concerning the redemption and salvation of man, but also relevant truths which put the whole of the cosmos in the correct perspective. He terms his approach in which Scripture is taken in= to account as a source of knowledge as the perspec= tive method. He warns that Scripture should not be used as a scientific textbook because this is not the intention of Scripture.

In the second instance science is practised by total man. This implies that the believer in Scrip= ture will be bound to scriptural truths which are applicable to the totality of his life. This means that the believer is bound to take the data of Scripture into consideration when he is busy with his scientific work. When it is taken into acccunt that all knowledge is focused on truth it follows that the truths which Scripture reveal and the truths formulated in science should in princi= ple not clash. This search for unity of all truth marks Stoker's efforts to formulate the principles of a Christian pursuit of science.

The distinction between God and cosmos in the third instance provides the basis upon which Stoker makes his classification of the sciences. He disting= uishes between theology, philosophy and the differ= ent special sciences. As a criterion for this distinction he uses the perspective which a scien= tist employs. This perspective brings a certain field of reserach into view, in the case of theolo= gy it is God as He is known from His revelation in Scripture and nature, in the case of philosophy it is the coherence of the diversity of reality where= is the special sciences concentrate on one of the diverse aspects of creation.

Stoker has also contributed much to the construc= tion of the groundwork of a Christian anthropology. In his anthropology he has also given an extensive discussion of the problem of human freedom.

In the field of ethics Stoker has also made his mark as a philosopher who consciously wants to 
construct a Christian theory of ethics.

It is evident that stoker has contributed much to the furtherance of the ideals of a Christian science and a Christian philosophy as a basis for the work of a Christian university. Many special scientist who have studied the work of Stoker have also implemented the principles which he formulated in their specific branch of special science. In this respect he has had a profound influence on the formation of a body of Christian scholarship in South Africa.

One cannot refrain from drawing attention to the fact that the differing approaches of Dooyeweerd and stoker have been interpreted as two rival and incompatable schools of philosophical thought. This was certainly not the intention of the two philosophers. It must be taken into account that a development of the body of the sciences in the perspective of the philosophical principles for= mulated by the two philosophers exhibit diver= gence on different fundamental points with the re= sult that followers of these different nuances within the ideal of a Christian philosophy tend to use the philosophical framework or system of either the one or the other philosopher. In the light of these developments one can see a marked divergence in the future development of the ideal of Christian scholarship in South Africa.

Apart from the two main streams other nuances have also come to the fore. This implies that although the basic idea of Christian academic work originat= ed with Kuyper's majestic view of the Lordship of Christ over all aspects of life, this conception has been channelled into differend philosophical channels which all bear to some or other extent the qualification "reformed" but still digress on salient points.

Apart from the various nuances within the philoso= phies of the various representatives of a Christian philosophy, it can be stated that much progress has been made in the realization of the original ideal which was initiated by Calvin, Kuyper and later proponents and introduced into South Africa via the 
Reformed church and its Theological School, the establishment of the Christian university of Pot= chefstroom and other organizations such as the "Vereniging vir Christelike Hoër Onderwys".

In conclusion the most recent developments concern= ing the construction of a body of Christian scien= tific knowledge and the implementation of Christian philosophical principles in the educational frame= work of the university of Potchefstroom will be discussed.

Recent developments

Apart from the efforts of individual scholars, the PU for $\mathrm{CHE}$ has consciously developed a positive Christian world and life view by giving students the opportunity to attend special lectures in which the basic truths of the calvinistic world and life view are expounded.

The current course called Interfaculty Philosophy is an effort to provide students with a broad outline of the most important cultural and historical trends, the basic elements of a Calvinistic philos= ophy and the Calvinistic life and world view.

This course, which is a compulsory course for all students has been preceeded by a few similar courses such as "Geloofsleer" (Doctrine of faith), "Principles and methods of science" and "Studium universale".

In these lectures students are acquainted with the basic philosophical presumptions of a Calvinistic world and life view and a Calvinistic philosophy. This course is also meant to treat explicitly the philosophical problems with which students are con= fronted in the different sciences they study.

It is evident that a Christian philosophy and Christian science can only be taught at an institu= tion which acknowledges the relevance of Christian principles to science and education.

This approach has been criticised by many as 
indoctrination and as incompatible with the charac= ter of either science or a university. It is clear that such a point of view departs from a different definition of the character of science or the task of the university.

The idea of a Christian university is built upon the presumption that all education is based on a spiritual basis which cannot be separated from the education a child receives in his own home. If spiritual values related to the religious convic= tions of the parents play a role in the everyday education of a child in the home, then these prin= ciples must also be acknowledged in science as such and the education given to the child and student outside of his home.

This implies that in the body of science, knowledge must be acquired and taught which do not contradict the basic principles incorporated in the life and world view of the student or scientist. This re= quirement of course creates many practical problems for example when the world and life view of the parents have been conditioned not in the first place by their confession of faith but by a certain temporary form of such a confession which often causes contradictions with scientific claims. In this respect the typical geocentric world view of many of the biblical authors may influence Christ= ians not to accept the latest findings of science whereas such a view of the world should be seen in the context of the historical period in which the book of the Bible was written. Apart from this very definite historical colouring of Biblical ma= terial, there are fundamental scriptural principles which are valid for all times and which also condi= tion the way Christians interpret man, the world and history. Recent developments with respect to the course in Interfaculty Philosophy have been in= strumental in the propagation of the idea of Chris= tian scholarship and Christian philosophy in the realm of the special sciences.

In future this course which has up to now been a general course, will be decentralized so that each separate faculty of the university will take re= sponsibility for its own Interfaculty Philosophy. 
This will create the opportunity to start the groundwork of the different philosophies of the special sciences from the fundamental framework which has been provided by a general Christian philosophy.

It is clear that such a venture can only be a long term program and that results will only be seen after this practical course has been implemented for quite a period of time.

M Elaine Botha

PU for CHE 
References

1. "Gereformeerd" with a capital designates the church denomi= nation. Without the dapital it designates the reformed or reformatory tradition.

2. Dooyeweerd $\mathrm{H}$, A new crituque of theoretical thought. Amsterdam, 1953, 523, 524.

3. Dooyeweerd explicitly rejects the name Calvinistic philosophy and states that his philosophy is meant to be a christian philosophy without any other qualification. vide Dooyeweerd, A new critique of theoretical thought I, 524

4. Conradie A L, The neo-Calvinistic concept of philosophy. Natal, 1960, 2

5. Stoker H G, Die nuwere wysbegeerte aan de Vrije Universi= teit. Reprint from: Die Wagtoring, 1932/33, 11.

6. Conradie, op cit, 2,9 .

7. Ibid, 32 .

8. Dooyeweerd, A new critique, $I, 41$.

9. Young w, Toward a reformed philosophy, Grand Rapids, 1952, 28 .

10. Dooyeweerd, op cit, I, 41 .

11. Ibid, 68,69 .

12. Young, op cit, 144. Botha M E, Soslo-kulturele metavrae. Buijten en Schipperheijn, Amsterdam, 1971, 148.

13. Conradie, op cit, 96-98.

14. Malan D J, 'n Kritiese studie van die Wysbegeerte van H G Stoker vanuit dle standpunt van $H$ Dooyeweerd, Amsterdam, 1968 .

15. Dooyeweerd, op cit, I, 10.

16. Heyns J A, Denkers deur die eeue. Kaapstad, 1967, 161-174. 